\title{
challenges
}

ISSN 2078-1547

www.mdpi.com/journal/challenges

Article

\section{Resilience, Sustainability and Risk Management: A Focus on Energy}

\author{
Benjamin McLellan *, Qi Zhang, Hooman Farzaneh, N. Agya Utama and Keiichi N. Ishihara \\ Graduate School of Energy Science, Kyoto University, Yoshida honmachi, Sakyo-ku, \\ Kyoto 606-8501, Japan; E-Mails: zhangqi@energy.kyoto-u.ac.jp (Q.Z.); \\ hooman.farzaneh.2v@kyoto-u.ac.jp (H.F.); utama.nukiagya.4c@kyoto-u.ac.jp (N.A.U.); \\ ishihara@energy.kyoto-u.ac.jp (K.N.I.)
}

* Author to whom correspondence should be addressed; E-Mail: b-mclellan@energy.kyoto-u.ac.jp; Tel.: +81-75-753-9173; Fax: +81-75-753-4745.

Received: 1 May 2012; in revised form: 21 June 2012 / Accepted: 23 July 2012 /

Published: 8 August 2012

\begin{abstract}
The natural and subsequent human disasters of March 11, 2011 in Japan have brought into focus more than ever the importance of resilience and risk mitigation in the construction of energy infrastructure. This article introduces some of the critical issues and discusses the implications of energy in alleviating or exacerbating the risks of natural disasters. Additionally, it presents a framework for considering the risks of energy systems from a broad perspective. The connection is drawn between design for sustainability and the risks associated with energy systems in natural disasters. As a result of the assessment, six criteria are proposed for energy systems to contribute to societal resilience in the face of natural disasters - they should be: (1) Continuous; (2) Robust; (3) Independent; (4) Controllable; (5) Non-hazardous; and (6) Matched to demand.
\end{abstract}

Keywords: sustainability; risk; resilience; distributed; infrastructure; energy; emissions

\section{Introduction}

Energy is one of the keys to the development of nations and society — one of the vital lifelines that keeps societies and economies functioning. Civilization is dependent on a constant, consistent supply of energy; globally the demand for energy has been increasing consistently in parallel with growth in 
population and economic consumption [1]. However, the hazards associated with energy are also important to recognize - the risks associated with technology as well as the risks associated with the cutting of energy supply.

Given the widespread impact and publication of the accident at the nuclear power station in Fukushima, the risk of nuclear power has again been brought into the limelight. However, each of the alternative energy systems also has risks - some far less obvious than others. For example, some of the first images of earthquake damage in Japan on March 11th were of fires and explosions occurring at LPG storage facilities at an oil refinery [2]. Moreover, it has been identified that, although renewable energy technologies such as solar panels may not have been damaged by the earthquake or tsunami, in the aftermath in many cases they continued to operate, even when the converters may have been damaged, thus creating an additional electrical hazard while not providing useful electricity [3].

This paper aims to build a framework for the consideration of risks associated with energy systems and to highlight failures in the aftermath of the March 11 disasters of 2011 that should ideally be avoided in future. The paper examines key energy systems in a variety of configurations and applications in order to present a comprehensive overview of the failures and advantages of the different alternatives. Furthermore, the consideration of risk is broadened to include alternative sustainability-related risks that are regularly ignored or under-examined in technological assessments of risk [4]. In particular, the paper addresses the potential beneficial contribution of energy systems in times of natural disaster.

Risk assessment and evaluation approaches in the design phase of processes and energy systems has been common practice since the late 1970's or early 1980's in many countries [5-7] - however, many current large scale power plants were designed prior to this. In terms of safety, there is empirical evidence that such assessments have reduced loss of life and infrastructure [8-10]. Some work has been done regarding infrastructure more generally with regards to climate change adaptation and the potential additional natural disaster risks that may be anticipated [11]. However, these approaches have largely focused on the operation's internal infrastructural integrity rather than seeking to incorporate sustainability risks, although some consideration to environmental risk has been given [12]. There is an opportunity, or indeed an urgent need, to use such structured techniques to identify risks and mitigation options beyond the plant gate — a boundary which is partially bridged by this study.

\subsection{Resilience and Vulnerability}

Resilience and vulnerability are terms utilized as approximate antonyms in this study. The interrelations and origins of research in the fields of resilience and vulnerability will not be covered in depth, as they have been widely reviewed and discussed elsewhere-e.g., [13,14]. However, characteristics of resilience have been summarized as [15]:

1. The amount of change the system can undergo and still retain the same controls on function and structure.

2. The degree to which the system is capable of self-reorganization to accommodate external changes.

3. The ability to build and increase the capacity for learning and adaptation.

On the other hand, vulnerability has been defined as having components that include [16]: 
1. Sensitivity to perturbations or external stresses

2. The (lack of) capacity to cope or adapt

3. Exposure to perturbations.

The context of the current study is on energy systems and their impact on sustainability - especially when exposed to natural disasters. Therefore, the definition of vulnerability in this case is "susceptibility of the energy system, or component thereof, to damage due to a natural disaster, resulting in loss of key functions or significant negative impact on sustainability". Resilience is then defined as "the ability of an energy system, or component thereof, to withstand damage due to a natural disaster, to have a benign or negligible impact on sustainability in case of damage or loss, and to contribute in a positive way to societal recovery post-disaster."

In regards to the context of the present work, there have been a number of studies that have analyzed factors of resilience in energy systems. The geographical characteristics affecting the resilience - both in terms of vulnerability and response/regeneration time - are discussed in terms of the electrical distribution system, highlighting particular factors of importance such as population density and land use [17]. Electricity systems at the national scale have also been quantitatively analyzed using a set of resilience indicators that include such items as "carbon intensity" and "diversity" of generation, but this again has not delved specifically into the technological aspects of energy systems and does not explicitly address sustainability concerns [18]. Synergistic opportunities of integration of waste and energy [19] and of water networks [20] have highlighted the balance between efficiency and resilience (integration often improving efficiency, but potentially adding to vulnerability).

\subsection{Sustainability}

Sustainability is a term that has been widely used and interpreted in a variety of ways. In most cases the definitions revert to some form of expression of the importance of preserving, enhancing and balancing the triple-bottom-line (TBL) of environment, economy and society. Often the "Brundtland" definition of sustainable development (SD) is utilized as a default: "development that meets the needs of the present without compromising the ability of future generations to meet their own needs" [21]. In the current work, we will largely follow this trend, taking sustainability to be a state of dynamic interplay between environment and society that ultimately contributes positively to indefinite human development and wellbeing whilst not overdrawing natural resources or over-burdening the environment in an irreversible manner. Rather than applying a TBL approach however, we use the "five capitals" framework (natural, social, human, manufactured and economic capital) [22] as the basis of our assessment. In this framework, the capitals refer to:

1. Natural-the natural environment, including all environmental services and environmental quality

2. Social-the networks or organizations that connect individuals

3. Human-the individual's characteristics and wellbeing - notably skills, education and health

4. Manufactured-the built environment and infrastructure

5. Economic-monetary transactions and wealth. 
Sustainability research has significant links to work in the field of resilience and vulnerability. Some examples of the connections have been in research on sustainable cities, which highlight the vulnerability of critical infrastructure as an important factor in the design of sustainable cities and the resilience of those cities [23]. Specifically, analysis has been conducted into the synergies between infrastructure planning for the reduction of risk in the event of terrorist or technological disasters and the potential reduction of environmental impacts [24]. The ecological, social and economic connectivity of the global society, and its vulnerability to environmental disruptions, have also been examined [25]. Likewise, the specific implications of environmental degradation in exacerbating natural disasters have been reviewed in light of the Indian Ocean Tsunami, showing some strong connections between the ultimate impact of the disaster and the vulnerabilities induced by policy decisions [26]. Some interesting work on full-cost accounting that applied the four capitals (excluding economic) has also tried to delve into the broader costs of coastal disasters [27]—although the focus was not specifically energy and therefore less detailed than the current approach.

Sustainability of energy is also an area that has been focused on by academics, politicians and industry across the world-e.g., [28-31]. The application of both centralized and decentralized renewable energy systems has been one specific focus for the integrated analysis of energy-sustainability-resilience. Renewable energy as a distributed energy technology providing diversity of generation and enhancing local skills and employment has been examined in detail $[32,33]$, while the challenges of creating an entirely independent energy region have been shown to be particularly high [34], and may not be ideal in terms of resilience across annual fluctuations of renewable energy sources. On the larger scale, hydropower development in China as a renewable energy source has been highlighted as introducing a mixture of vulnerability and resilience due to the potential impacts on a large (often transboundary) community and environment and the necessity of good governance and stakeholder engagement [35].

Sustainability and resilience are often the topic of post-construction analysis and assessment. However, in terms of ability to improve operational performance in both safety and sustainability, it is important to consider the earlier stages of development [36]. Sustainability in design or "design for sustainability" (DfS) seeks to incorporate considerations of sustainability into the system even before it is constructed - which is often the most economically feasible timing as well as giving the highest sustainability impact and reducing risk [4,37,38]. Various frameworks and tools have been developed for measuring and incorporating sustainability [39], but these approaches are generally considered from the perspective of normal operations rather than from unusual conditions such as natural disasters (which are mostly considered in safety or risk management studies). Two such DfS approaches are considered here as an introduction to the potential implications on safety and resilience of energy systems in natural disasters of using a sustainability framework for design.

The first approach is "Green Engineering", with its 12 principles [40] to assist in improving the environmental performance of industrial operations or processes (of which the eight directly relevant principles are given in Table 1). It is apparent from the resilience considerations for energy that correspond to these principles, that in many cases there is a direct correlation between the design for environment and the resilience of the system in disasters. 
Table 1. Principles of "Green Engineering" [40] and considerations of resilient energy systems.

\begin{tabular}{|c|c|c|}
\hline & Principles & Resilience considerations for energy \\
\hline 1 & $\begin{array}{l}\text { Designers need to strive to ensure that all material } \\
\text { and energy inputs and outputs are as inherently } \\
\text { nonhazardous as possible. }\end{array}$ & $\begin{array}{l}\text { Non-hazardous flows do not pose an exacerbated } \\
\text { threat in a disaster situation. }\end{array}$ \\
\hline 2 & $\begin{array}{l}\text { It is better to prevent waste than to treat or clean } \\
\text { up waste after it is formed. }\end{array}$ & $\begin{array}{l}\text { Reducing waste produced in regular operations } \\
\text { reduces storage of waste and potential for release } \\
\text { in a disaster. }\end{array}$ \\
\hline 3 & $\begin{array}{l}\text { Products, processes and systems should be "output } \\
\text { pulled" rather than "input pushed" through the use } \\
\text { of energy and materials. }\end{array}$ & $\begin{array}{l}\text { Energy systems driven by output will likely be } \\
\text { readily ramped down or up subsequent to } \\
\text { disaster-related demand shift. }\end{array}$ \\
\hline 4 & $\begin{array}{l}\text { Targeted durability, not immortality, should be a } \\
\text { design goal. }\end{array}$ & $\begin{array}{l}\text { Durability of infrastructure needs to correspond to } \\
\text { potential disasters. }\end{array}$ \\
\hline 5 & $\begin{array}{l}\text { Design for unnecessary capacity or capability } \\
\text { (e.g., "one size fits all") solutions should be } \\
\text { considered a design flaw. }\end{array}$ & $\begin{array}{l}\text { Flexible operation however, can be useful in } \\
\text { disaster situations. }\end{array}$ \\
\hline 6 & $\begin{array}{l}\text { Design of products, processes and systems must } \\
\text { include integration and interconnectivity with } \\
\text { available energy and materials flows. }\end{array}$ & $\begin{array}{l}\text { Utilization of locally available energy and } \\
\text { materials may enhance resilience when supply } \\
\text { lines are cut further afield. }\end{array}$ \\
\hline 7 & $\begin{array}{l}\text { Products, processes and systems should be } \\
\text { designed for performance in a commercial } \\
\text { "afterlife". }\end{array}$ & $\begin{array}{l}\text { Subsequent to disaster, in the worst case } \\
\text { infrastructure should be reusable for alternative } \\
\text { applications. }\end{array}$ \\
\hline 8 & $\begin{array}{l}\text { Material and energy inputs should be renewable } \\
\text { rather than depleting. }\end{array}$ & $\begin{array}{l}\text { Renewable inputs are likely to be less hazardous } \\
\text { and may rely less on long supply chains-although } \\
\text { they may be vulnerable in some disaster situations. }\end{array}$ \\
\hline
\end{tabular}

The second framework considered is the Waste Minimization Hierarchy (WMH), which is shown in Figure 1. This figure gives some examples of initiatives that correspond to each of the five levels of the WMH and that have benefits in reducing either the severity or probability of a hazard, which in turn reduces the overall risk to environment and society from an operation. This approach to reducing environmental impacts from waste can also thus be utilized in improving energy system robustness in the face of natural disasters.

It is apparent from these two methodologies that there is strong linkage and potential between the use of sustainability principles, tools or frameworks in the design of energy systems and the development of more resilient systems. The framework applied in the remaining assessment of risk and resilience is the "five capitals" framework [22] which was described earlier.

\section{Methodology}

The current work employs a systematic methodology for identifying risks, vulnerabilities and opportunities for their mitigation. This methodology has been adapted from earlier work that applied a similar assessment to minerals industry projects [4]. The focus is broader than just technical risk, seeking to identify sustainability risks using the "five capitals" framework [22] to break down the sustainability components of energy systems. The examination specifically focuses on the vulnerability of different energy systems to natural disasters, and the subsequent impact or benefit that the energy system can have in disaster situations. Because the study examines energy systems under unusual circumstances of natural disasters, it does not take into account the standard operational impacts which are the consideration of most of the standard literature on risk and the externalities of energy [41-43]. 
Figure 1. Waste minimization hierarchy and its relationship to reducing the severity and probability of hazards.

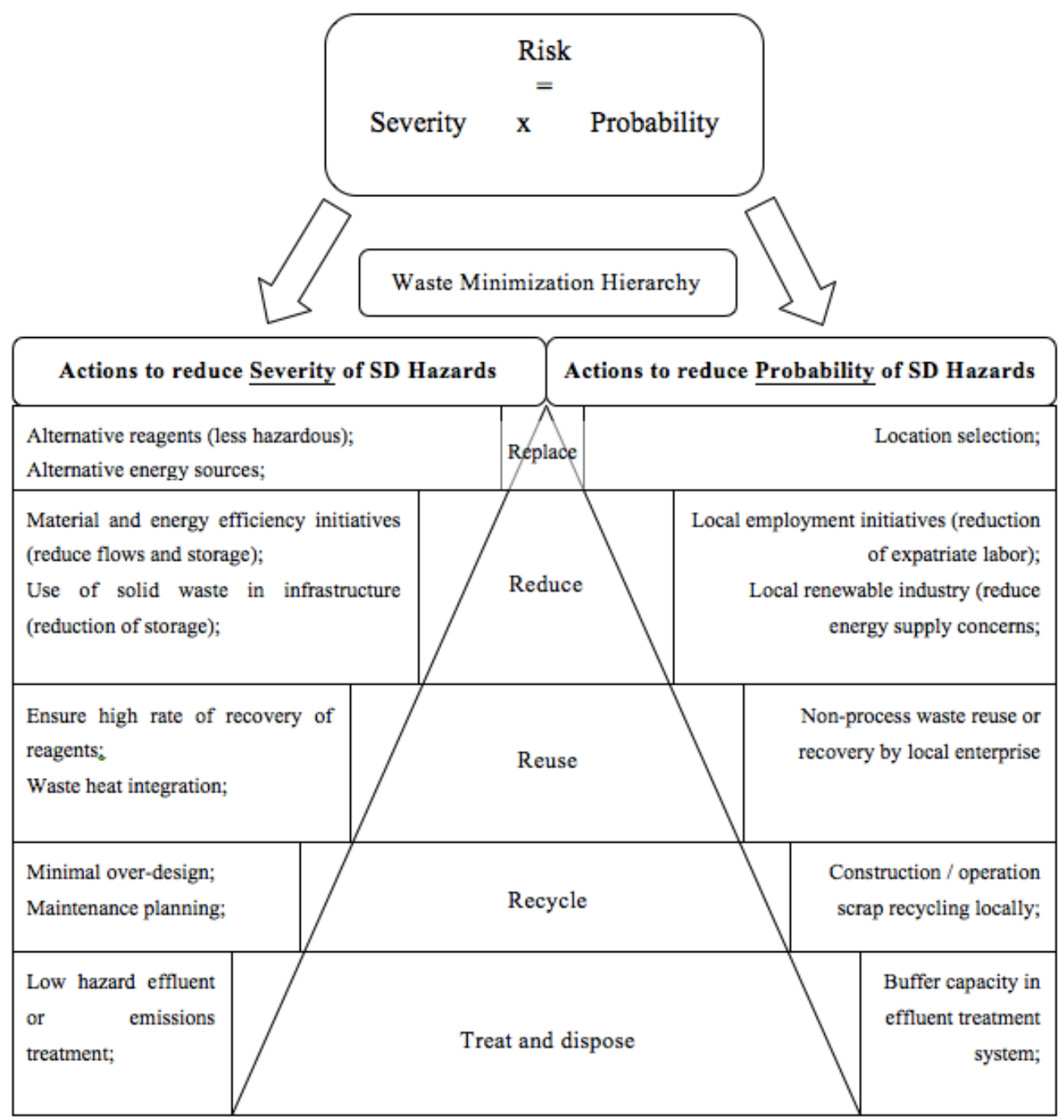

The alternative energy systems considered in this assessment are representative of the key modern energy sources - both conventional fossil fuels and the more recently expanding renewable energy technologies. In this case, the energy systems are not analyzed down to the unit process level, as might be the case with a more rigorous technical assessment that might occur during the design or licensing of an operation - using techniques such as Hazard and Operability (HAZOP) studies for example [44,45]. Rather, in this study, we examine only the major flows and operational conditions that are identified as posing a particularly high risk by virtue of the magnitude of their volume, toxicity or energy content. Being focused on sustainability, the study also examines the flow-on effects of damage to the energy system.

The methodology first breaks the energy system down into inputs, outputs and internal operationsin this way covering the key aspects of the supply chain and emissions/wastes that could be affected by a natural disaster (see Figure 2). The assessment also includes the fuel extraction operations as a separate section but not the facilities that produce the equipment used in the energy systems - although these can certainly be affected by natural disasters. The specific flows and operations that were 
identified using this framework, and subsequently examined, are shown in Table 2 for the energy generating facilities and Table 3 for the fuel extraction and transportation stages of the supply chain. In the following step, the vulnerabilities of each of the key inputs, outputs and internal operations are analyzed through a structured HAZOP-like process. (In this case, we apply a subset of HAZOP guide words and a "grey box" model of the energy systems - focusing only on high influence operations to identify hazards.) Subsequently, the resulting potential impacts of natural disasters damaging the energy system are listed against the five capitals framework.

Figure 2. Input-operation-output diagram for the risk assessment.

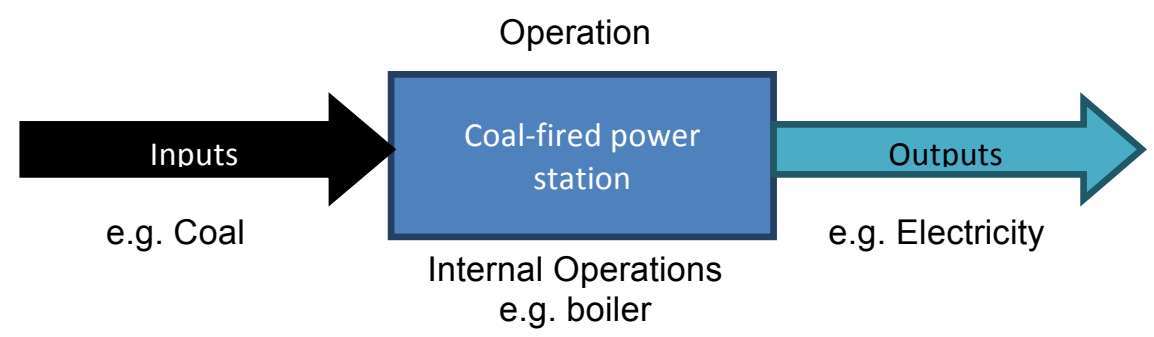

Table 2. Inputs-internal operations-outputs for alternative energy systems and sub-components.

\begin{tabular}{|c|c|c|c|}
\hline Energy system & Inputs & Internal operations & Outputs \\
\hline \multirow[t]{4}{*}{ Nuclear power } & Nuclear fuel & Reactor & Electricity \\
\hline & Water & Cooling system & Steam and heated water \\
\hline & Electricity & Steam cycle & Spent fuel \\
\hline & & Spent fuel storage & \\
\hline \multirow[t]{4}{*}{ Coal-fired power } & Coal & Boiler & Electricity \\
\hline & Water & Steam cycle & Steam \\
\hline & Oxidant (Air) & Tailings storage & Flue gas \\
\hline & & Coal storage & Ash \\
\hline \multirow[t]{3}{*}{ Natural gas-power } & Natural gas & Combustion turbine & Electricity \\
\hline & Water & Steam cycle & Steam \\
\hline & Oxidant (Air) & Fuel storage & Flue gas \\
\hline \multirow[t]{2}{*}{ Natural gas-heat/fuel } & Natural gas & $\begin{array}{l}\text { Fuel } \\
\text { storage/transmission }\end{array}$ & Heat \\
\hline & Oxidant (Air) & Combustor/engine & Flue gas \\
\hline \multirow[t]{3}{*}{ Oil-power } & Oil & Combustion engine & Electricity \\
\hline & Water & Fuel storage & Flue gas \\
\hline & Oxidant (Air) & & Heated water \\
\hline \multirow[t]{2}{*}{ Oil-heat/fuel } & Oil & Fuel storage & Heat \\
\hline & Oxidant (Air) & Combustor/engine & Flue gas \\
\hline \multirow[t]{2}{*}{ Hydro power } & Water & Dam & Electricity \\
\hline & & Turbines & Water \\
\hline Geothermal & Water & Steam cycle & Water \\
\hline \multirow[t]{2}{*}{ Wind } & Air & Turbine & Electricity \\
\hline & & & Air \\
\hline \multirow[t]{2}{*}{ Solar-PV } & Sunlight & PV panels & Electricity \\
\hline & & Batteries (optional) & \\
\hline Solar-Thermal & Sunlight & Thermal collector & Hot water \\
\hline
\end{tabular}


Table 3. Extraction and transportation stages considered for the assessment.

\begin{tabular}{lll}
\hline Energy system & Extraction & Transportation \\
\hline Uranium & Mining & Road \\
& $\begin{array}{l}\text { In-situ leaching } \\
\text { Tailings storage }\end{array}$ & Ship \\
Coal & Mine & Rail/conveyor \\
& Tailings storage & Ship \\
& Coal storage & \\
Natural gas & Well extraction & Pipeline \\
& Fuel storage & Ship \\
Oil & Well extraction & Pipeline \\
& Fuel storage & Ship \\
Biomass & Harvesting & Road/Rail \\
\hline
\end{tabular}

In most considerations of resilience, there is a focus on the system as a whole rather than individual elements as isolated nodes [46]. However in this case, we focus largely on the key energy generating equipment, as the vulnerability of such elements is the most crucial component and in most cases the most hazardous. However, in order to examine some of the systemic impacts and vulnerabilities, in addition to the identification of technology-specific risks, general configurations of energy systems and the ability for alternative systems to enhance societal resilience in the face of disaster are also examined. Furthermore, two key components-labor and the electricity grid-are considered separately due to their influence on every energy system. Finally, this analysis draws on significant examples from the March 11th disaster in Japan in 2011 to highlight the practical reality of energy systems in disaster situations.

\section{Results}

The described methodology was applied to the flows and operations in Table 2 and Table 3. The resultant detailed responses to the HAZOP-type assessment are provided in the Appendix (Table A1-A4). From these responses, the general resilience and vulnerability statements associated with hazard categories that are associated with most energy systems are summarized in Table 4, while Table 5 then highlights the key risks from each of the energy systems on the five capitals, based on the worst case scenario for a variety of natural disasters. The particular disasters to which given systems were considered to be most susceptible given the technology, location and recent examples, are also indicated in the far right hand column. Some general categories of vulnerability, common to most energy systems - labor, supply chains and the electricity grid, are discussed further in section 4, and are therefore not elaborated on in these tables. The first row of Table 5 further highlights some of the key impacts on the five capitals that arise from given natural disasters. 
Table 4. System components vulnerability and resilience.

\begin{tabular}{|c|c|c|}
\hline Component & Vulnerability & Resilience \\
\hline Fuel supply chain & $\begin{array}{l}\text { Long supply chain-import facility or transport loss } \\
\text { exposure } \\
\text { Short supply chain-vulnerable to simultaneous damage }\end{array}$ & $\begin{array}{l}\text { Long supply chain less vulnerable to simultaneous damage } \\
\text { Short supply chain can allow continued or rapid-recovery of } \\
\text { operations }\end{array}$ \\
\hline Fuel storage & $\begin{array}{l}\text { Onsite storage can be damaged and cause fire, } \\
\text { explosion, contamination or other health and } \\
\text { environmental hazards }\end{array}$ & $\begin{array}{l}\text { Onsite storage can enable continued operation despite supply-chain } \\
\text { loss. } \\
\text { Frequency of fuel delivery directly related to onsite storage capacity } \\
\text { and usage rate: } \\
\quad \text { Nuclear fuel-infrequent delivery makes damage unlikely; } \\
\quad \text { Hydrocarbon fuel-sufficient onsite storage allows operation } \\
\quad \text { during recovery; }\end{array}$ \\
\hline Fuel characteristics & $\begin{array}{l}\text { Flammable or explosive fuels provide high energy but } \\
\text { increase hazard of storage; } \\
\text { Liquid fuels likely to pool or disperse in waterways; }\end{array}$ & $\begin{array}{l}\text { Solid fuels are less likely to disperse widely; } \\
\text { Gaseous fuels will disperse widely and rapidly; }\end{array}$ \\
\hline
\end{tabular}


Table 4. Cont.

\begin{tabular}{|c|c|c|}
\hline Component & Vulnerability & Resilience \\
\hline Waste storage & $\begin{array}{l}\text { Onsite storage can be damaged and dispersed: } \\
\text { Large volume, low level waste such as ash from } \\
\text { coal or biomass or } \\
\text { Low volume, high level waste such as spent } \\
\text { nuclear fuel }\end{array}$ & \\
\hline $\begin{array}{l}\text { Non-fuel energy } \\
\text { sources }\end{array}$ & $\begin{array}{l}\text { Wind-vulnerable to overly windy (e.g., storm or cyclone } \\
\text { conditions); } \\
\text { Water-hydro and ocean energy can be damaged by } \\
\text { spikes in influx; } \\
\text { (Hydro dam damage most critical hazard) } \\
\text { Water-hydro power is dependent upon water inflow; } \\
\text { Sunlight-solar power vulnerable to overcast conditions } \\
\text { associated with storm activity; panels vulnerable to hail } \\
\text { and high winds; }\end{array}$ & $\begin{array}{l}\text { Non-fuel sources except water are only temporarily interruptible-- } \\
\text { short term recovery is likely; } \\
\text { Geothermal heat is unlikely to spike or trough; } \\
\text { Dam construction is often designed specifically for flood mitigation } \\
\text { and can reduce the scale and intensity of negative impacts of high } \\
\text { rainfall. }\end{array}$ \\
\hline Electricity output & $\begin{array}{l}\text { Grids vulnerable to flooding and high wind particularly; } \\
\text { Lack of output has serious societal impact; } \\
\text { Larger grids lead to higher impact; } \\
\text { Continued output to damaged grid is hazardous to health } \\
\text { and equipment; }\end{array}$ & $\begin{array}{l}\text { Continued output can support societal recovery; } \\
\text { Most generation facilities can rapidly decrease generation-but } \\
\text { restarting after long lay-off is most difficult for nuclear or coal; }\end{array}$ \\
\hline
\end{tabular}


Table 5. Major risks of impact on the five capitals of generic natural disasters and alternative energy systems.

\begin{tabular}{|c|c|c|c|c|c|c|}
\hline & Human & Social & Economic & Manufactured & Natural & \\
\hline $\begin{array}{l}\text { Disaster direct } \\
\text { impact on } \\
\text { capitals }\end{array}$ & $\begin{array}{l}\text { Health and life } \\
\text { Access to facilities } \\
\text { Skills loss }\end{array}$ & $\begin{array}{l}\text { Support networks } \\
\text { Consumer loss }\end{array}$ & $\begin{array}{l}\text { Loss of revenue } \\
\text { Cost of repair } \\
\text { Flow-on loss of } \\
\text { productivity } \\
\end{array}$ & $\begin{array}{l}\text { Loss of facilities } \\
\text { Damage to facilities }\end{array}$ & $\begin{array}{l}\text { Loss of populations or } \\
\text { habitats } \\
\text { Loss of regular } \\
\text { environmental services }\end{array}$ & \\
\hline System impacts & $\begin{array}{l}\text { Health-minor fire } \\
\text { risk }\end{array}$ & $\begin{array}{l}\text { Moderate impacts } \\
\text { associated with loss of } \\
\text { electricity }\end{array}$ & $\begin{array}{l}\text { Moderate impacts } \\
\text { associated with loss of } \\
\text { electricity }\end{array}$ & Minor fire risk & & $\begin{array}{l}\text { Disaster } \\
\text { susceptibility } \\
\text { Bush fire; } \\
\text { Flooding; } \\
\text { Gale force winds; }\end{array}$ \\
\hline Coal & $\begin{array}{l}\text { Health-fire or } \\
\text { contamination }\end{array}$ & $\begin{array}{l}\text { Major impacts } \\
\text { associated with loss of } \\
\text { electricity }\end{array}$ & $\begin{array}{l}\text { Major impacts associated } \\
\text { with loss of electricity }\end{array}$ & Fire risk & & $\begin{array}{l}\text { Bush fire; } \\
\text { Earthquake; } \\
\text { Flooding; } \\
\text { Gale force winds; } \\
\text { Tsunami; }\end{array}$ \\
\hline Gas & Health-fire & $\begin{array}{l}\text { Moderate impacts } \\
\text { associated with loss of } \\
\text { electricity }\end{array}$ & $\begin{array}{l}\text { Moderate impacts } \\
\text { associated with loss of } \\
\text { electricity }\end{array}$ & Fire or explosion risk & & $\begin{array}{l}\text { Bush fire; } \\
\text { Earthquake; } \\
\text { Flooding; } \\
\text { Gale force winds; } \\
\text { Tsunami; }\end{array}$ \\
\hline Geothermal & $\begin{array}{l}\text { Health-minor } \\
\text { contamination } \\
\text { possible }\end{array}$ & Minor loss of electricity & Minor loss of electricity & - & $\begin{array}{l}\text { Minor contamination } \\
\text { possible }\end{array}$ & $\begin{array}{l}\text { Earthquake; } \\
\text { Flooding; }\end{array}$ \\
\hline Hydro & $\begin{array}{l}\text { Health-dam break } \\
\text { flash flooding risk; }\end{array}$ & $\begin{array}{l}\text { Minimal to major } \\
\text { impacts associated with } \\
\text { loss of electricity; } \\
\text { Dislocation-flooding } \\
\text { destruction; }\end{array}$ & $\begin{array}{l}\text { Minimal to major impacts } \\
\text { associated with loss of } \\
\text { electricity and flooding; } \\
\text { Loss of workforce; } \\
\text { Loss of revenue; } \\
\text { Loss of consumer base; }\end{array}$ & $\begin{array}{l}\text { Loss of infrastructure } \\
\text { by flash flooding; }\end{array}$ & $\begin{array}{l}\text { Silt and relocated water } \\
\text { pattern impact on ecology; }\end{array}$ & $\begin{array}{l}\text { Earthquake; } \\
\text { Severe flooding; }\end{array}$ \\
\hline
\end{tabular}


Table 5. Cont.

\begin{tabular}{|c|c|c|c|c|c|c|}
\hline & Human & Social & Economic & Manufactured & Natural & \\
\hline Nuclear & $\begin{array}{l}\text { Health-long term } \\
\text { contamination } \\
\text { Loss of employment } \\
\end{array}$ & $\begin{array}{l}\text { Dislocation-long term } \\
\text { contamination }\end{array}$ & $\begin{array}{l}\text { Loss of workforce } \\
\text { Loss of consumer base }\end{array}$ & & Long term contamination & $\begin{array}{l}\text { Earthquake; } \\
\text { Tsunami; }\end{array}$ \\
\hline Oil & $\begin{array}{l}\text { Health-fire or } \\
\text { contamination }\end{array}$ & $\begin{array}{l}\text { Moderate impacts } \\
\text { associated with loss of } \\
\text { electricity }\end{array}$ & $\begin{array}{l}\text { Moderate impacts } \\
\text { associated with loss of } \\
\text { electricity }\end{array}$ & Fire or explosion risk & $\begin{array}{l}\text { Moderate medium term } \\
\text { impacts on local species } \\
\text { from fire or contamination; }\end{array}$ & $\begin{array}{l}\text { Bush fire; } \\
\text { Flooding; } \\
\text { Earthquake; } \\
\text { Tsunami; }\end{array}$ \\
\hline Solar & $\begin{array}{l}\text { Health- } \\
\text { electrocution risk }\end{array}$ & $\begin{array}{l}\text { Minor impacts } \\
\text { associated with loss of } \\
\text { electricity }\end{array}$ & $\begin{array}{l}\text { Minor impacts associated } \\
\text { with loss of electricity; } \\
\text { Cost of repair could be } \\
\text { significant proportional to } \\
\text { supply; }\end{array}$ & - & - & $\begin{array}{l}\text { Flooding; } \\
\text { Tsunami; } \\
\text { Gale force winds; }\end{array}$ \\
\hline Tidal/wave & & $\begin{array}{l}\text { Potential shipping } \\
\text { hazard; } \\
\text { Minor to moderate } \\
\text { impacts associated with } \\
\text { loss of electricity; }\end{array}$ & $\begin{array}{l}\text { Minor to moderate impacts } \\
\text { associated with loss of } \\
\text { electricity; }\end{array}$ & $\begin{array}{l}\text { Equipment coming } \\
\text { loose may become an } \\
\text { additional floating } \\
\text { hazard; }\end{array}$ & - & Tsunami; \\
\hline Wind & - & $\begin{array}{l}\text { Minor impacts } \\
\text { associated with loss of } \\
\text { electricity }\end{array}$ & $\begin{array}{l}\text { Minor impacts associated } \\
\text { with loss of electricity; }\end{array}$ & $\begin{array}{l}\text { Turbine towers may } \\
\text { topple, causing } \\
\text { damage to nearby } \\
\text { capital; }\end{array}$ & Minor fire risk; & Gale force winds; \\
\hline
\end{tabular}




\section{Discussion}

It can be seen from the results shown in the previous section (Table 4 and Table 5) that, in general, non-fuel-based renewable energy technologies are less hazardous - both during operation and in a natural disaster situation - largely due to the lower intensity of operating conditions. The exception is hydropower, which under most conditions would support resilience but may, under particular circumstances such as earthquakes or exceptionally high rainfall, add to a disaster through dam failure and consequent flooding. However, renewable energy technologies have vulnerabilities that may make them particularly susceptible to poor performance during natural disasters. For example, wind turbines must be shut off during high winds, making them useless in storms or cyclones - although they were shown to perform well in the March 11 earthquake and tsunami [47]. Likewise, solar photovoltaics may not produce sufficient electricity in overcast conditions that would also be associated with storm or rainfall-associated disasters.

The following subsections highlight some of the major specific impacts of energy systems in natural disasters.

\subsection{General Factors Affecting Vulnerability}

Some characteristics of energy systems may be generalized across all alternative systems - in particular, the configuration of these systems as centralized or decentralized. Although there are many discussions as to what exactly defines a decentralized or distributed system (some useful definitions elsewhere $[48,49])$, in general, such systems should provide energy to a relatively small number of users in a limited geographic area. Typical of decentralized energy systems would be small scale generators supplying rural communities or solar panels providing energy for a single home. At the other end of the scale, centralized energy systems rely on economy of scale, with large scale production that is distributed over a wide area for numerous users-examples include typical modern nuclear and coal-fired power plants connected to the electricity grid. Table 6 highlights some of the key impact factors and the important aspects of time and diversity that can support or adversely affect resilience.

Damage to infrastructure can present many risks that are unassociated with the infrastructure's use in the energy system - for example, hazards associated with falling objects or drowning. Such risks are not considered in detail here, but may be associated with loss of operating conditions, loss of labor, loss of control of the system and thereby exacerbate the natural disaster.

Two key factors in the resilience of energy systems can be highlighted as: diversification and prioritization. Diversification is typical of distributed energy systems that utilize renewable energy produced by a variety of small to medium-sized generators [32]. The key resilience factor of diversity is that it is less likely for multiple sources of energy to be cut off or damaged than for a single source. However, the level of skills, care and maintenance applied to larger, centralized systems may also be an advantage for preventing damage in a disaster. The larger, centralized systems also typically gain priority from government and corporate stakeholders who wish to see the largest consumer base supply recovered the quickest [17]. This can mean that the smaller generators take longer to be repaired and may also present a hazard to health and environment for a longer time. 
Table 6. Factors affecting risk and vulnerability of centralized or decentralized energy systems.

\begin{tabular}{|c|c|c|c|}
\hline Configuration & Impact factors & Time & Diversity \\
\hline Centralized & $\begin{array}{l}\text { Larger number } \\
\text { of dependent users; } \\
\text { Typically larger } \\
\text { scale storage of } \\
\text { feedstocks and waste; } \\
\text { Typically more } \\
\text { intense operating } \\
\text { conditions (temperatures } \\
\text { and pressures); } \\
\text { Wide-spread impact; }\end{array}$ & $\begin{array}{l}\text { Larger infrastructure leads to } \\
\text { longer delay for reconstruction; } \\
\text { Priority often given for } \\
\text { reconstruction because } \\
\text { of larger user base; }\end{array}$ & $\begin{array}{l}\text { Low diversification- } \\
\text { vulnerable to specific } \\
\text { feedstock loss; }\end{array}$ \\
\hline Decentralized & $\begin{array}{l}\text { Localized impact; } \\
\text { Smaller number of users; }\end{array}$ & $\begin{array}{l}\text { Shorter delay to start-up; } \\
\text { Lower-priority for } \\
\text { reconstruction in many cases; }\end{array}$ & $\begin{array}{l}\text { Higher diversification- } \\
\text { more robust to loss of } \\
\text { single feedstock; }\end{array}$ \\
\hline
\end{tabular}

\subsection{Labor Risks}

Energy systems cannot be considered separate from the society they support. One key non-infrastructure component of energy systems that may be generalized across many alternative systems is the labor input. Small-scale renewable energy systems are generally autonomous, with labor only required for installation and maintenance-however, for all other systems some level of human control is inevitable. Natural disasters can be alleviated or exacerbated by the response of those in control - for recent examples: flood mitigation in south-east Queensland (January 2011) and the Fukushima nuclear power plant. However, an additional consideration is the ability of the labor force to attend work to keep the energy system operating. In the case of a natural disaster, access to installations is often hampered, and it may fall to those operating the plant at the time of the disaster to continue working for extended periods until access and labor relief is achieved. This risk was particularly exposed by the nuclear accident at Fukushima, in which new laws needed to be passed so that operators could continue to work at the plant beyond their previous yearly limit of radiation exposure. The ability to maintain a sufficient workforce with the requisite skills will be boosted by operations requiring low onsite staffing, but with large local or regional workforce. This is likely to benefit sustainability from a socio-economic perspective during normal operations as well as facilitating recovery from natural disasters. Decentralized renewable energy technologies may be favored from this perspective [32,33] — especially in cases where ongoing deployment of technologies has enabled the growth of skills for maintenance within the area [37].

\subsection{Transmission and Distribution Network Risks}

Under the current paradigm of energy generation and distribution, large scale, centralized production feeds extensive networks of users via the electricity grid. Grid damage presents a risk to all centralized energy systems - and subsequently to their customers. (Moreover, grid electricity loss is an additional hazard in nuclear systems that require an external energy supply for safety during shutdown.) Whilst most modern emergency facilities, hospitals and some other commercial or 
government facilities may have back-up electricity supplies (on-site generator), the onsite storage of fuel is limited and may not be sufficient if transportation infrastructure is also damaged. Above ground infrastructure for suspending transmission lines is susceptible to high winds and strong flood waters in particular, while underground electrical infrastructure can be damaged by flooding [11]. Damaged energy distribution networks can also pose a hazard to health —electrification or fire risk.

\subsection{Supply Chain Impacts}

Significant both in terms of general operational fuel cycle impacts and in terms of vulnerability to natural disasters are the supply chain elements from extraction of fuel and distribution of fuel to electricity generating facilities. The analysis of supply chain vulnerabilities in Table A4 highlighted a number of key points. Firstly, the mining or extraction of fuels and its subsequent impact on the energy system is largely related to the distance of separation between the extraction and usage, and the frequency of delivery. Natural gas delivered by pipeline directly into a distribution network or coal delivered to a mine-gate power plant is vulnerable to immediate and prolonged disruption of electricity generation. By contrast, the mining of uranium or disruption to coal transported to distant power plants is likely to have a lower or delayed impact, due to the infrequency of delivery.

In general, thermal coal is shipped relatively short distances, as is biomass. This implies that energy systems using these fuels are more likely to be simultaneously impacted by a natural disaster, whereas nuclear, oil or liquefied natural gas plants are likely to use fuels of more distant origin and therefore less likely to be simultaneously interrupted. The impacts of natural disasters are in most cases likely to be similar for the extraction, delivery and generation stages of the life cycle, although potentially the extraction phase will involve larger volumes of material- e.g., a whole mine or an oil well compared to a single oil or coal storage facility.

\subsection{Contribution in Times of Natural Disaster}

In natural disasters, swift and safe search, rescue and recovery efforts are highly dependent on available energy resources. This is true both for organized emergency response and for independent household recovery. Without fuel, emergency generators, vehicles and equipment cannot run. Without electricity, communications, coordination and evacuation facilities are impotent. Therefore it is imperative that energy systems are resilient and contribute safely to the ongoing provision of energy in the event of a natural disaster. However, onsite storage or continued generation in the case of damaged facilities may contribute to exacerbating the disaster by creating an electrical or fire hazard. Some key criteria that would delineate resilient and non-resilient energy systems are discussed briefly in this section.

In order to support communities hit by natural disasters, energy systems must be:

1. Continuous - operating safely throughout or restarting safely immediately post-disaster

2. Robust - not easily damaged in case of potential natural disasters

3. Independent - able to operate for a continuous period (in the order of days to weeks) post-disaster without relying on physical intervention from outside (local source of energy or sufficient storage, and with an appropriate local skills base to operate) 
4. Controllable - able to be readily shut-down or with output adjusted depending on conditions

5. Non-hazardous - able to provide energy in a way that does not cause an additional unwarranted hazard

6. Matched to demand - able to provide energy in the form and quantity that is needed, in the location it is needed, when it is needed

Continuous operation is closely linked to robustness and controllability, in that the physical impact of a given natural disaster on the energy system impacts the ability of the system to continue to operate and its controllability under non-ideal operating conditions. This robustness is related both to the mode of the disaster and the physical location, materials, support structures, mode of operation and disaster defenses of the energy system. For example, solar photovoltaics are often roof-mounted, making them less vulnerable to flood damage but more vulnerable to high winds. Controllability of the system under normal and abnormal operating conditions is often the result of initial design, and can be particularly affected by the choice of electronic or physical control. Often in response to disaster, energy systems can only be controlled in a single direction or across a small band of operating conditions-e.g., wind power increases until the cut-out speed, when the turbine is stopped; nuclear power automatically shuts down.

The importance of independent generation is never more starkly highlighted than in times of natural disaster. Many energy systems can run relatively autonomously under normal conditions - with only external monitoring and occasional maintenance. However, if generators are shut down for safety prior to a disaster, or if they sustain damage due to the disaster, then external intervention is typically necessary - especially when remote operation becomes impossible due to grid or communication network damage. Independence for a period of days is often possible with relatively low storage capacity onsite. However, longer periods require access to energy sources locally or through the reopening of fuel supply routes. Independence is also closely tied to matching with demand. In most modern societies, electricity, oil and gas are the most ubiquitous energy sources-electricity for power applications and oil and gas for heating, cooking and for transportation. Natural disasters can often cause links in the supply chain to be cut. Due to the inflexibility of most household energy structures, and the "lock-in" to electricity for appliances or petroleum for transportation, the designed end use becomes inoperable without an external fuel supply of the required type (e.g., conventional gasoline cars will not run on electricity, and neither will electric stoves run on gas). Matching demand in situations of natural disaster may require the ability to operate flexibly in the production of alternative energy carriers (which, for instance, may be a benefit of fossil fuel-based energy systems or of hydrogen energy systems [50]) or having sufficient spare capacity to expand generation to cover for loss elsewhere in the system.

Finally, the aspect of being non-hazardous (either inherently, or by control) is of key importance in disasters. Of the examined energy systems, perhaps the least hazardous is geothermal, given that it relies on relatively low heat, and that heat is a more readily detectible hazard than electricity for humans. Furthermore, geothermal energy systems can be readily shut down to avoid leakage. Wind power and hydro will in most circumstances also be relatively non-hazardous. On the other hand, the storage of fuels in nuclear and thermal power plants presents an inherent risk, which is only mitigated by sound infrastructure design and control. 


\section{Conclusions}

One of the key requirements of energy systems that promote resilient societies in the face of natural disasters is that the energy system itself is resilient to natural disasters. This paper has examined various existing energy systems from the perspective of hazards posed to and by the energy system in the case of natural disasters.

The current work highlights the connection between sustainability and resilience in the design of energy systems. It is specifically highlighted that frameworks for improving the operational sustainability performance of energy systems can also provide benefits of reducing risks in times of natural disaster. The five capitals model of sustainability is also applied to help identify the risks beyond the plant boundary.

As a result of the assessment, six key criteria for energy systems to contribute to the resilience of a community in the face of natural disasters are highlighted, indicating that energy systems should be: (1) Continuous; (2) Robust; (3) Independent; (4) Controllable; (5) Non-hazardous; and (6) Matched to demand. Energy systems that correspond to these criteria will contribute to sustainable development in both standard operation and in times of extraordinary hardship.

Regarding these criteria, geothermal energy is regarded as one of the technologies that most contributes to societal sustainability. Non-renewable technologies tend to involve hazardous materials, while renewable energy systems may be hazardous if uncontrolled. Supply of energy from local sources is positive for rapid recovery but may mean that all stages of the supply chain are damaged simultaneously, in which case distant sources of energy may be preferred from a vulnerability perspective.

\section{References}

1. IEA. World Energy Outlook 2008; International Energy Agency: Paris, France, 2008.

2. COSMO Oil Co. Ltd. Lpg tanks fire extinguished at chiba refinery (5th update). Available online: http://www.cosmo-oil.co.jp/eng/information/110321/index.html (accessed on 26 March 2011).

3. Kurokawa, K. Exploiting all the possibilities of PV power generation. In From Post-Disaster Reconstruction to the Creation of Resilient Societies; Keio University: Tokyo, Japan, 2011.

4. McLellan, B.C.; Corder, G.D. Risk reduction through early assessment and integration of sustainability in design in the minerals industry. J. Clean. Prod. 2012, doi:10.1016/ j.jclepro.2012.02.014

5. Kletz, T.A. Hazop-past and future. Reliab. Eng. Syst. Saf. 1997, 55, 263-266.

6. Kletz, T.A. The origins and history of loss prevention. Process Saf. Environ. Prot. 1999, 77, 109-116.

7. Swann, C.D.; Preston, M.L. Twenty-five years of hazops. J. Loss Prev. Process Ind. 1995, 8, 349-353.

8. Kletz, T. Incidents that could have been prevented by hazop. J. Loss Prev. Process Ind. 1991, 4, 128-129.

9. Groves, W.A.; Kecojevic, V.J.; Komljenovic, D. Analysis of fatalities and injuries involving mining equipment. J. Saf. Res. 2007, 38, 461-470. 
10. Pitblado, R. Global process industry initiatives to reduce major accident hazards. J. Loss Prev. Process Ind. 2011, 24, 57-62.

11. Engineering the Future. Infrastructure, Engineering and Climate Change Adaptation-Ensuring Services in An Uncertain Future; The Royal Academy of Engineering: London, UK, 2011; p. 107.

12. García-Serna, J.; Pérez-Barrigón, L.; Cocero, M.J. New trends for design towards sustainability in chemical engineering: Green engineering. Chem. Eng. J. 2007, 133, 7-30.

13. Vogel, C.; Moser, S.C.; Kasperson, R.E.; Dabelko, G.D. Linking vulnerability, adaptation, and resilience science to practice: Pathways, players, and partnerships. Glob. Environ. Chang. 2007, 17, 349-364.

14. Turner, B.L., II. Vulnerability and resilience: Coalescing or paralleling approaches for sustainability science? Glob. Environ. Chang. 2010, 20, 570-576.

15. Wardekker, J.A.; de Jong, A.; Knoop, J.M.; van der Sluijs, J.P. Operationalising a resilience approach to adapting an urban delta to uncertain climate changes. Technol. Forecast. Soc. Chang. 2010, 77, 987-998.

16. Manuel-Navarrete, D.; Gómez, J.J.; Gallopín, G. Syndromes of sustainability of development for assessing the vulnerability of coupled human-environmental systems. The case of hydrometeorological disasters in central America and the Caribbean. Glob. Environ. Chang. 2007, 17, 207-217.

17. Maliszewski, P.J.; Perrings, C. Factors in the resilience of electrical power distribution infrastructures. Appl. Geogr. 2012, 32, 668-679.

18. Molyneaux, L.; Wagner, L.; Froome, C.; Foster, J. Resilience and electricity systems: A comparative analysis. Energy Policy 2012, 47, 188-201.

19. Kharrazi, A.; Masaru, Y. Quantifying the sustainability of integrated urban waste and energy networks: Seeking an optimal balance between network efficiency and resilience. Procedia Environ. Sci. 2012, 13, 1663-1667.

20. Li, Y.; Yang, Z.F. Quantifying the sustainability of water use systems: Calculating the balance between network efficiency and resilience. Ecol. Model. 2011, 222, 1771-1780.

21. World Commission on Environment and Development. Our Common Future; Oxford University Press: Oxford, UK, 1987; p. 347.

22. Forum for the Future The five capitals. Available online: http://www.forumforthefuture.org/ project/five-capitals/overview (accessed on 12 September 2011).

23. Branscomb, L.M. Sustainable cities: Safety and security. Technol. Soc. 2006, 28, 225-234.

24. Coaffee, J. Risk, resilience, and environmentally sustainable cities. Energy Policy 2008, 36, 4633-4638.

25. Kissinger, M.; Rees, W.E.; Timmer, V. Interregional sustainability: Governance and policy in an ecologically interdependent world. Environ. Sci. Policy 2011, 14, 965-976.

26. Srinivas, H.; Nakagawa, Y. Environmental implications for disaster preparedness: Lessons learnt from the indian ocean tsunami. J. Environ. Manag. 2008, 89, 4-13.

27. Gaddis, E.B.; Miles, B.; Morse, S.; Lewis, D. Full-cost accounting of coastal disasters in the united states: Implications for planning and preparedness. Ecol. Econ. 2007, 63, 307-318. 
28. Afgan, N.H.; Gobaisi, D.A.; Carvalho, M.G.; Cumo, M. Sustainable energy development. Renew. Sustain. Energy Rev. 1998, 2, 235-286.

29. Kinrade, P. Toward a sustainable energy future in australia. Futures 2007, 39, 230-252.

30. Lee, S.-C.; Shih, L.-H. Enhancing renewable and sustainable energy development based on an options-based policy evaluation framework: Case study of wind energy technology in taiwan. Renew. Sustain. Energy Rev. 2011, 15, 2185-2198.

31. Lior, N. Sustainable energy development (May 2011) with some game-changers. Energy 2012, $40,3-18$.

32. O'Brien, G.; Hope, A. Localism and energy: Negotiating approaches to embedding resilience in energy systems. Energy Policy 2010, 38, 7550-7558.

33. del Río, P.; Burguillo, M. An empirical analysis of the impact of renewable energy deployment on local sustainability. Renew. Sustain. Energy Rev. 2009, 13, 1314-1325.

34. Schmidt, J.; Schönhart, M.; Biberacher, M.; Guggenberger, T.; Hausl, S.; Kalt, G.; Leduc, S.; Schardinger, I.; Schmid, E. Regional energy autarky: Potentials, costs and consequences for an austrian region. Energy Policy 2012, 47, 211-221.

35. McNally, A.; Magee, D.; Wolf, A.T. Hydropower and sustainability: Resilience and vulnerability in china's powersheds. J. Environ. Manag. 2009, 90, S286-S293.

36. Corder, G.D.; McLellan, B.C.; Green, S.R. Delivering solutions for resource conservation and recycling into project management systems through susop ${ }^{\circledR}$. Miner. Eng. 2012, 29, 47-57.

37. Corder, G.D.; McLellan, B.C.; Bangerter, P.J.; van Beers, D.; Green, S.R. Engineering-in sustainability through the application of susop ${ }^{\circledR}$. Chem. Eng. Res. Des. 2012, 90, 98-109.

38. McLellan, B.C.; Corder, G.D. Designing-in Sustainability in Industrial Projects and Processes. In Proceedings of EcoDesign 2011-7th International Symposium on Environmentally Conscious Design and Inverse Manufacturing, Kyoto, Japan, 30 November-2 December 2011; Matsumoto, M., Umeda, Y., Masui, K., Fukushige, S., Eds.; Springer: Kyoto, Japan, 2011.

39. McLellan, B.C.; Corder, G.D.; Giurco, D.; Green, S. Incorporating sustainable development in the design of mineral processing operations-review and analysis of current approaches. J. Clean. Prod. 2009, 17, 1414-1425.

40. Anastas, P.T.; Zimmerman, J.B. Design through the 12 principles of green engineering. Environ. Sci. Technol 2003, 37, 94A-101A.

41. Burgherr, P.; Hirschberg, S. Severe accident risks in fossil energy chains: A comparative analysis. Energy 2008, 33, 538-553.

42. Inhaber, H. Risk with energy from conventional and nonconventional sources. Science 1979, 203, 718-723.

43. Ricci, P.F.; Cirillo, M.C. Health risks analysis of energy systems: Issues and approaches. Environ. Int. 1984, 10, 367-376.

44. Crawley, F.; Preston, M.; Tyler, B. Hazop: Guide to Best Practice: Guidelines to Best Practice for the Process and Chemical Industries; Institution of Chemical Engineers: London, UK, 2000.

45. Kletz, T.A. Hazop and Hazan: Identifying and Assessing Process Industry Hazards; The Institution of Chemical Engineers: London, UK, 1999.

46. Fiksel, J. Sustainability and resilience: Towards a systems approach. Sustain. Sci. Pract. Policy 2006, 2, 14-21. 
47. Ushiyama, I. Activities on Offshore Wind Power Generation in Japan. In Proceedings of World Ocean Forum, Busan, Korea, 26-28 October 2011.

48. Ackermann, T.; Andersson, G.; Söder, L. Distributed generation: A definition. Electr. Power Syst. Res. 2001, 57, 195-204.

49. Alanne, K.; Saari, A. Distributed energy generation and sustainable development. Renew. Sustain. Energy Rev. 2006, 10, 539-558.

50. Afgan, N.; Veziroglu, A. Sustainable resilience of hydrogen energy system. Int. J. Hydrog. Energy 2012, 37, 5461-5467. 


\section{Appendix}

Table A1. Adapted-HAZOP assessment of risks associated with inputs of energy systems (blank = not applicable).

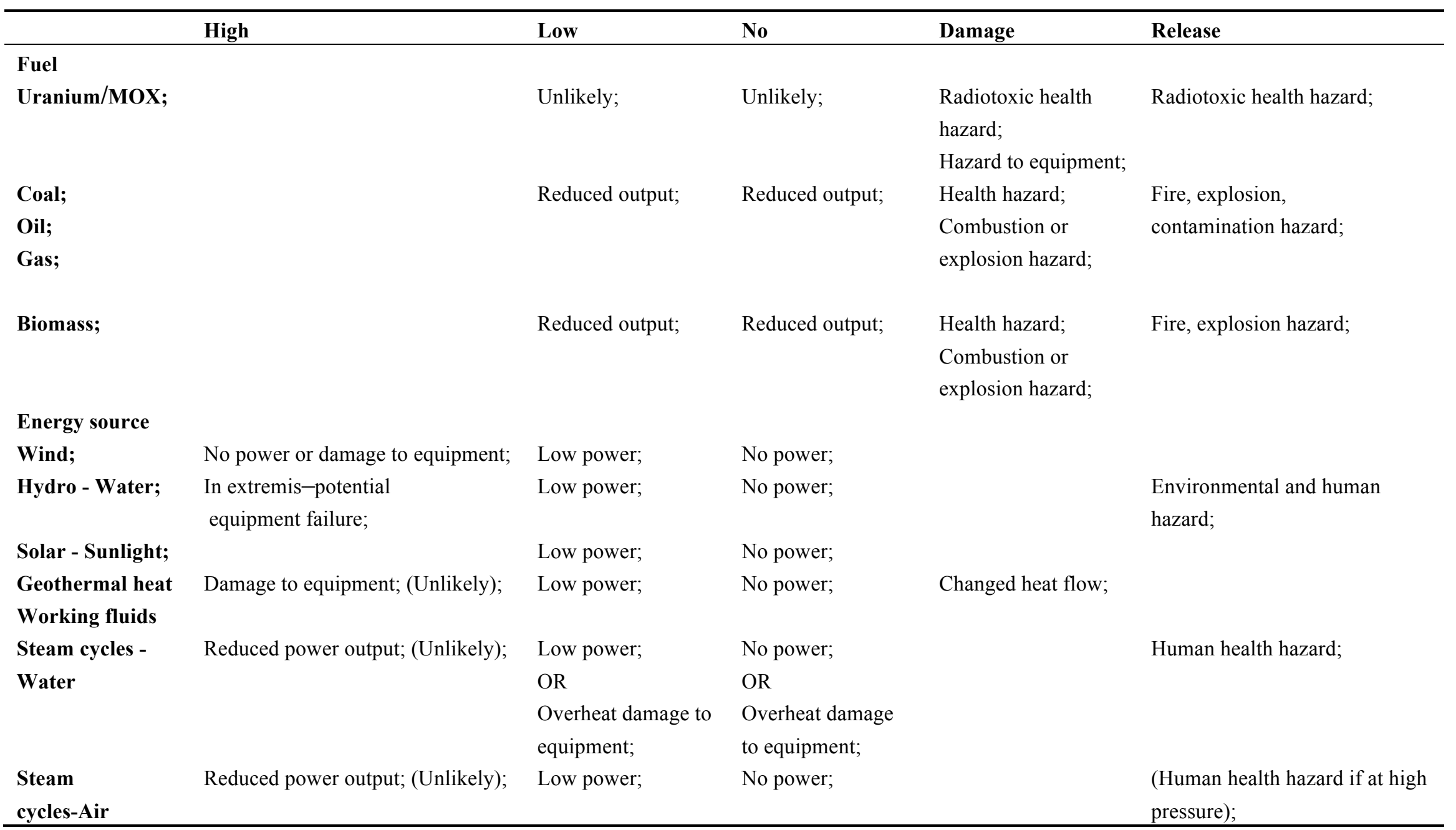


Table A2. Adapted-HAZOP assessment of risks associated with outputs of energy systems.

\begin{tabular}{|c|c|c|c|c|c|}
\hline & High & Low & No & Damage & Release \\
\hline \multicolumn{6}{|l|}{ Energy product } \\
\hline Electricity & Grid overload; & $\begin{array}{l}\text { Brown-out or black- } \\
\text { out risk to } \\
\text { community; }\end{array}$ & $\begin{array}{l}\text { Black-out risk } \\
\text { to community; }\end{array}$ & & Health hazard; \\
\hline Heat & $\begin{array}{l}\text { Health, environmental } \\
\text { and equipment hazard; }\end{array}$ & & & & \\
\hline \multicolumn{6}{|l|}{ Waste } \\
\hline Depleted & & & & Radiotoxic & Radiotoxic health hazard; \\
\hline Uranium/MOX fuel & & & & $\begin{array}{l}\text { health hazard; } \\
\text { Hazard to } \\
\text { equipment; }\end{array}$ & Hazard to equipment; \\
\hline Ash (coal/biomass) & Health hazard; & & & & Health and environmental hazard; \\
\hline Flue gas & $\begin{array}{l}\text { Health and } \\
\text { environmental hazard; }\end{array}$ & & & & Health and environmental hazard; \\
\hline
\end{tabular}

Table A3. Adapted-HAZOP assessment of risks associated with internal operations of energy systems (blank = not applicable).

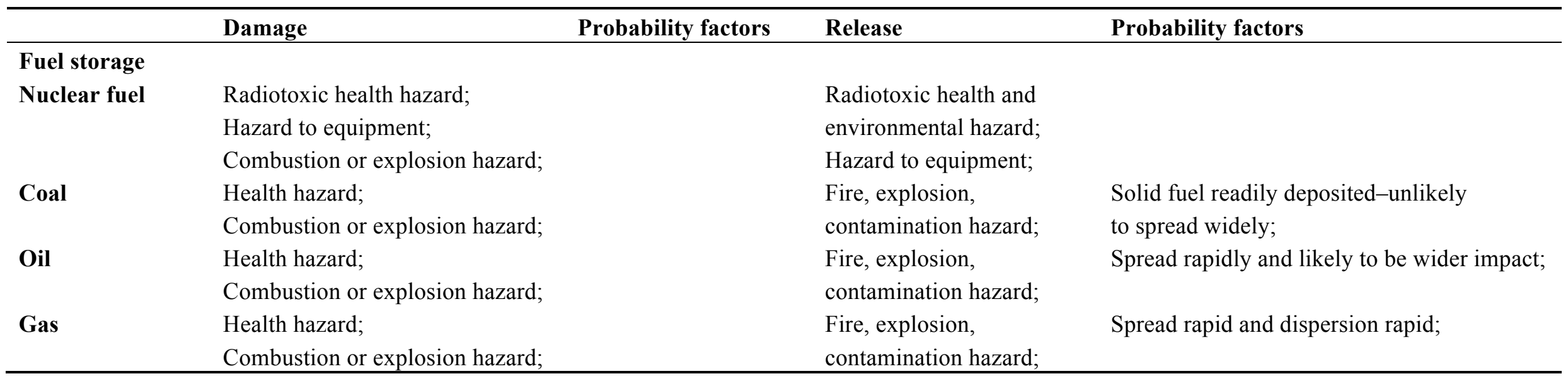


Table A3. Cont.

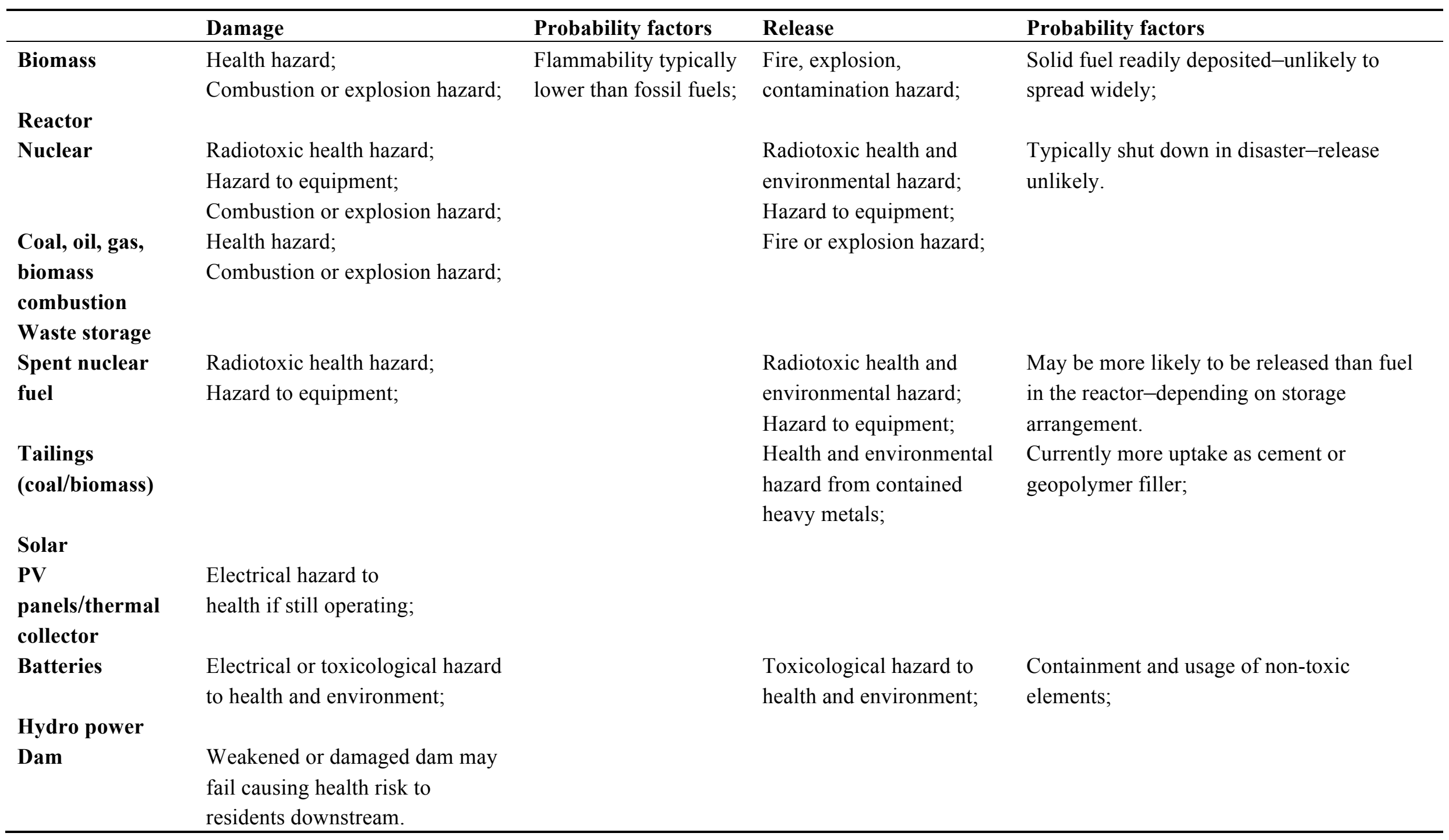


Table A4. Adapted-HAZOP assessment of risks associated with extraction and transportation stages (blank = not applicable).

\begin{tabular}{|c|c|c|c|c|c|}
\hline & Energy system component & Damage & Probability factors & Release & Probability factors \\
\hline \multicolumn{6}{|l|}{ Extraction } \\
\hline \multirow[t]{3}{*}{ Uranium } & Mine & $\begin{array}{l}\text { Flooding-fuel supply cut; } \\
\text { Earthquake-potential } \\
\text { damage to mine; }\end{array}$ & $\begin{array}{l}\text { Production rates flexible-- } \\
\text { delivery times infrequent } \\
\text { for individual power plants; }\end{array}$ & $\begin{array}{l}\text { Potential release of } \\
\text { radiotoxic materials; }\end{array}$ & $\begin{array}{l}\text { Likely release into } \\
\text { ground water; }\end{array}$ \\
\hline & In-situ leach & $\begin{array}{l}\text { Flooding-production } \\
\text { affected; } \\
\text { Earthquake-potential loss } \\
\text { of confinement; }\end{array}$ & $\begin{array}{l}\text { Production rates flexible-- } \\
\text { delivery times infrequent } \\
\text { for individual power plants; }\end{array}$ & $\begin{array}{l}\text { Potential release of } \\
\text { radiotoxic materials; }\end{array}$ & $\begin{array}{l}\text { Highly likely release } \\
\text { into ground water; }\end{array}$ \\
\hline & Tailings storage & $\begin{array}{l}\text { Flooding or earthquake-- } \\
\text { loss of confinement; }\end{array}$ & $\begin{array}{l}\text { Older mines with lower } \\
\text { remaining dam capacity } \\
\text { more likely; }\end{array}$ & $\begin{array}{l}\text { Potential release of } \\
\text { radiotoxic materials; }\end{array}$ & $\begin{array}{l}\text { Likely release to } \\
\text { land and seepage to } \\
\text { ground water; }\end{array}$ \\
\hline \multirow[t]{2}{*}{ Coal } & Mine & $\begin{array}{l}\text { Flooding, earthquake, bush } \\
\text { fire-short-medium-term } \\
\text { loss of production; } \\
\text { Gale force winds-short- } \\
\text { term loss of production; }\end{array}$ & $\begin{array}{l}\text { Fire-combustion products } \\
\text { and extended threat to } \\
\text { surrounding environment; } \\
\text { Mine at power plant gate- } \\
\text { loss of generation after } \\
\text { stockpiles run-out; } \\
\text { Mine and power plant } \\
\text { separated-option to } \\
\text { temporarily source coal } \\
\text { elsewhere; }\end{array}$ & $\begin{array}{l}\text { Flood/gale force } \\
\text { winds-coal dust } \\
\text { emissions to water or air; } \\
\text { Minor impacts to } \\
\text { environment and } \\
\text { human health; }\end{array}$ & $\begin{array}{l}\text { Likely release } \\
\text { due to wind; } \\
\text { Flood release only in } \\
\text { extreme circumstances; }\end{array}$ \\
\hline & Tailings storage & $\begin{array}{l}\text { Flooding, earthquake, bush } \\
\text { fire-potential damage to } \\
\text { storage dams; }\end{array}$ & $\begin{array}{l}\text { Widespread damage } \\
\text { depending on geography; }\end{array}$ & $\begin{array}{l}\text { Flood/earthquake-- } \\
\text { release of tailings-threat } \\
\text { to human life and } \\
\text { infrastructure; }\end{array}$ & $\begin{array}{l}\text { Tailings release risk } \\
\text { governed by geography } \\
\text { and tailings state } \\
\text { (dry or wet); }\end{array}$ \\
\hline
\end{tabular}


Table A4. Cont.

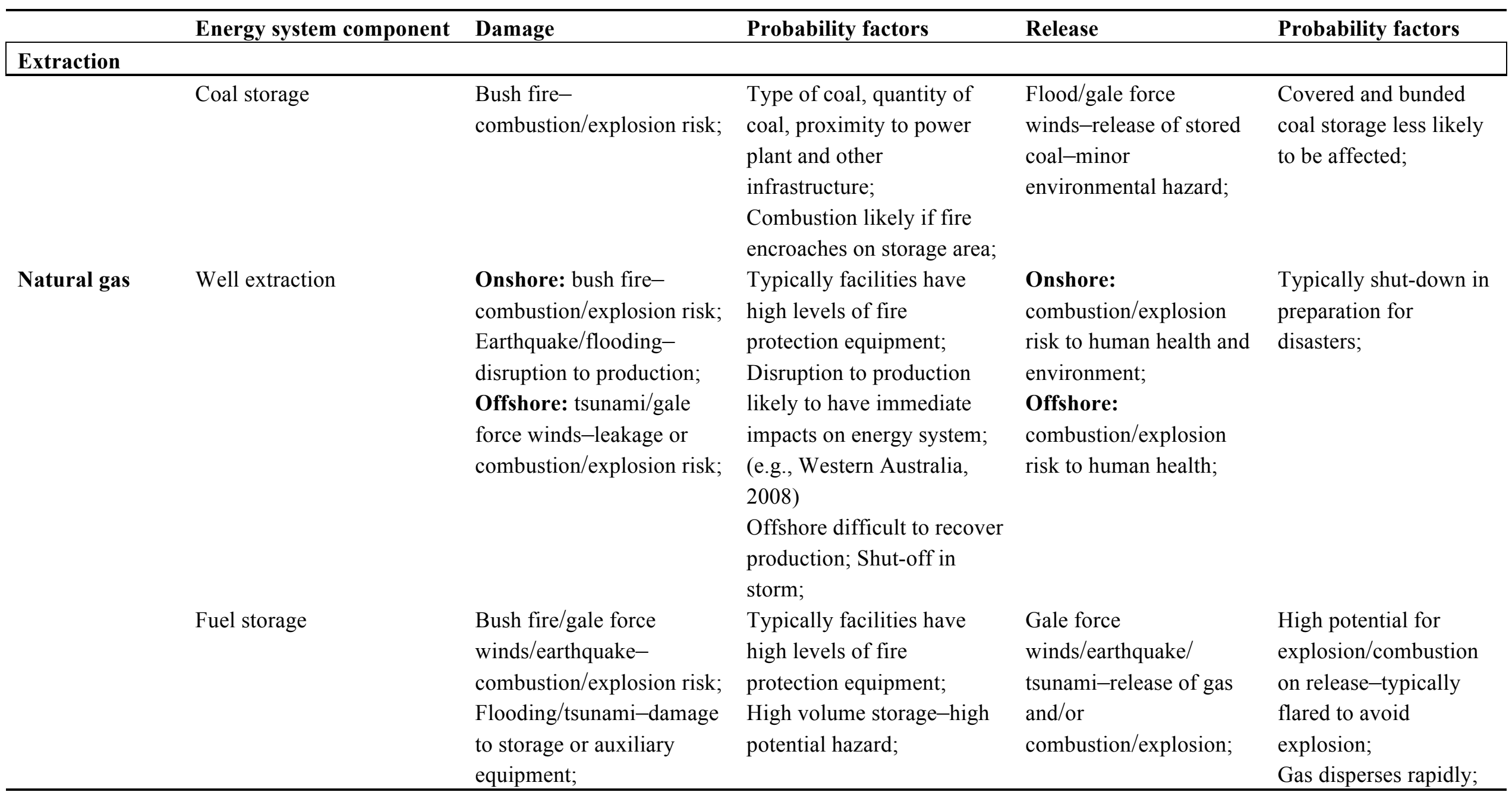


Table A4. Cont.

\begin{tabular}{|c|c|c|c|c|c|}
\hline & Energy system component & Damage & Probability factors & Release & Probability factors \\
\hline \multicolumn{6}{|c|}{ Extraction } \\
\hline Oil & Well extraction & $\begin{array}{l}\text { Onshore: bush fire-- } \\
\text { combustion risk; } \\
\text { Earthquake/flooding-- } \\
\text { leakage/disruption to } \\
\text { production; } \\
\text { Offshore: tsunami/gale } \\
\text { force winds-leakage or } \\
\text { combustion risk; }\end{array}$ & $\begin{array}{l}\text { Typically facilities have } \\
\text { high levels of fire } \\
\text { protection equipment; } \\
\text { Disruption may have } \\
\text { impact on oil prices and } \\
\text { availability (e.g., Gulf of } \\
\text { Mexico, 2010) } \\
\text { Offshore difficult to recover } \\
\text { production or stop leakage; } \\
\text { Shut-off in storm may } \\
\text { help prevent; }\end{array}$ & $\begin{array}{l}\text { Gale force } \\
\text { winds/earthquake/ } \\
\text { tsunami-release of oil } \\
\text { and/or } \\
\text { combustion/explosion; } \\
\text { Toxic/health impact in } \\
\text { aquatic environment; }\end{array}$ & $\begin{array}{l}\text { Containment difficult } \\
\text { in aquatic environment; }\end{array}$ \\
\hline & Fuel storage & & $\begin{array}{l}\text { Typically facilities have } \\
\text { high levels of fire } \\
\text { protection equipment; }\end{array}$ & $\begin{array}{l}\text { Fire, explosion, } \\
\text { contamination hazard; } \\
\text { Gale force } \\
\text { winds/earthquake/ } \\
\text { tsunami-release of oil } \\
\text { and/or combustion/ } \\
\text { explosion; }\end{array}$ & $\begin{array}{l}\text { Containment difficult } \\
\text { in aquatic environment; } \\
\text { Spread rapidly and } \\
\text { likely to be wider } \\
\text { impact; }\end{array}$ \\
\hline Biomass & Harvesting & Combustion hazard; & $\begin{array}{l}\text { Flammability typically } \\
\text { lower than fossil fuels; } \\
\text { Localized production of } \\
\text { fuel likely to have } \\
\text { significant impact on } \\
\text { generating capacity; }\end{array}$ & Fire hazard; & $\begin{array}{l}\text { Solid fuel readily } \\
\text { deposited-unlikely to } \\
\text { spread widely } \\
\text { especially if the } \\
\text { harvested biomass } \\
\text { consists of large } \\
\text { components; }\end{array}$ \\
\hline
\end{tabular}


Table A4. Cont.

\begin{tabular}{|c|c|c|c|c|c|}
\hline & Energy system component & Damage & Probability factors & Release & Probability factors \\
\hline \multicolumn{6}{|c|}{ Transportation } \\
\hline \multirow[t]{2}{*}{ Uranium } & Road & Radiotoxic leak hazard; & $\begin{array}{l}\text { Unlikely due to low } \\
\text { frequency, relatively low } \\
\text { volume, high security and } \\
\text { protective vessels; }\end{array}$ & Radiotoxic hazard; & $\begin{array}{l}\text { Unlikely due to low } \\
\text { frequency, relatively } \\
\text { low volume, high } \\
\text { security and protective } \\
\text { vessels; } \\
\text { Unlikely to spread } \\
\text { widely unless released } \\
\text { to water or via } \\
\text { fire/explosion into } \\
\text { atmosphere; }\end{array}$ \\
\hline & Ship & $\begin{array}{l}\text { Radiotoxic leak hazard-- } \\
\text { tsunami or gale force } \\
\text { winds sink or damage ship; }\end{array}$ & $\begin{array}{l}\text { Unlikely due to low } \\
\text { frequency, relatively low } \\
\text { volume, high security and } \\
\text { protective vessels; }\end{array}$ & Radiotoxic hazard; & $\begin{array}{l}\text { Unlikely due to low } \\
\text { frequency, relatively } \\
\text { low volume, high } \\
\text { security and protective } \\
\text { vessels; } \\
\text { Unlikely to spread } \\
\text { widely unless all } \\
\text { enclosing vessels } \\
\text { breached; }\end{array}$ \\
\hline
\end{tabular}


Table A4. Cont.

\begin{tabular}{|c|c|c|c|c|c|}
\hline & Energy system component & Damage & Probability factors & Release & Probability factors \\
\hline \multicolumn{6}{|c|}{ Transportation } \\
\hline \multirow[t]{2}{*}{ Coal } & Rail/conveyor & $\begin{array}{l}\text { Contamination, } \\
\text { combustion or explosion } \\
\text { hazard-bush fire, gale } \\
\text { force winds or flash } \\
\text { flooding; }\end{array}$ & $\begin{array}{l}\text { Fire-combustion products } \\
\text { and extended threat to } \\
\text { surrounding environment; } \\
\text { Mine at power plant gate- } \\
\text { loss of generation after } \\
\text { stockpiles run-out; } \\
\text { Mine and power plant } \\
\text { separated-option to } \\
\text { temporarily source coal } \\
\text { elsewhere; }\end{array}$ & $\begin{array}{l}\text { Fire, explosion, } \\
\text { contamination hazard; } \\
\text { Flood/gale force winds-- } \\
\text { coal dust emissions to } \\
\text { water or air; } \\
\text { Minor impacts to } \\
\text { environment and } \\
\text { human health; }\end{array}$ & $\begin{array}{l}\text { Likely release due to } \\
\text { wind; } \\
\text { Solid fuel readily } \\
\text { deposited-unlikely to } \\
\text { spread widely; }\end{array}$ \\
\hline & Ship & $\begin{array}{l}\text { Contamination, } \\
\text { combustion or explosion } \\
\text { hazard-gale force } \\
\text { winds or tsunami; }\end{array}$ & $\begin{array}{l}\text { Fire-human health } \\
\text { hazard limited to } \\
\text { onboard personnel; }\end{array}$ & $\begin{array}{l}\text { Fire and contamination } \\
\text { hazard; } \\
\text { Tsunami/gale force } \\
\text { winds-coal dust } \\
\text { emissions to water; } \\
\text { Minor impacts to } \\
\text { environment and human } \\
\text { health; }\end{array}$ & $\begin{array}{l}\text { Likely release due to } \\
\text { tsunami; } \\
\text { Solid fuel readily } \\
\text { deposited-unlikely to } \\
\text { spread widely; }\end{array}$ \\
\hline
\end{tabular}


Table A4. Cont.

\begin{tabular}{|c|c|c|c|c|c|}
\hline & Energy system component & Damage & Probability factors & Release & Probability factors \\
\hline \multicolumn{6}{|c|}{ Transportation } \\
\hline Natural gas & Pipeline & $\begin{array}{l}\text { Combustion or explosion } \\
\text { hazard--bush fire, } \\
\text { earthquake or gale force } \\
\text { winds; } \\
\text { Delivery disruption-- } \\
\text { earthquake or flooding; }\end{array}$ & $\begin{array}{l}\text { Fire likely if pipeline } \\
\text { damaged; } \\
\text { Disruption to delivery } \\
\text { causing significant energy } \\
\text { system disruption; }\end{array}$ & $\begin{array}{l}\text { Gale force } \\
\text { winds/earthquake- } \\
\text { release of gas and/or } \\
\text { combustion/explosion; }\end{array}$ & $\begin{array}{l}\text { High potential for } \\
\text { explosion/combustion } \\
\text { on release-typically } \\
\text { control system stops } \\
\text { flow in emergency; } \\
\text { Gas disperses rapidly; }\end{array}$ \\
\hline & Ship & $\begin{array}{l}\text { Contamination, } \\
\text { combustion or explosion } \\
\text { hazard -gale force winds } \\
\text { or tsunami; }\end{array}$ & $\begin{array}{l}\text { Fire-human health } \\
\text { hazard limited to onboard } \\
\text { personnel; }\end{array}$ & $\begin{array}{l}\text { Fire and contamination } \\
\text { hazard; } \\
\text { Tsunami/gale force } \\
\text { winds-coal dust } \\
\text { emissions to water; } \\
\text { Minor impacts to } \\
\text { environment and } \\
\text { human health; }\end{array}$ & $\begin{array}{l}\text { Likely release due to } \\
\text { tsunami; } \\
\text { Solid fuel readily } \\
\text { deposited-unlikely to } \\
\text { spread widely; }\end{array}$ \\
\hline Oil & Pipeline & $\begin{array}{l}\text { Combustion or explosion } \\
\text { hazard--bush fire, } \\
\text { earthquake or gale force } \\
\text { winds; } \\
\text { Delivery disruption-- } \\
\text { earthquake or flooding; }\end{array}$ & $\begin{array}{l}\text { Fire possible if pipeline } \\
\text { damaged; } \\
\text { Disruption to delivery } \\
\text { causing some energy } \\
\text { system disruption; }\end{array}$ & $\begin{array}{l}\text { Gale force } \\
\text { winds/earthquake- } \\
\text { release of oil and/or } \\
\text { combustion/explosion; }\end{array}$ & $\begin{array}{l}\text { High potential for } \\
\text { explosion/combustion } \\
\text { on release-typically } \\
\text { control system stops } \\
\text { flow in emergency; } \\
\text { Spread rapidly in water } \\
\text { and likely to be wider } \\
\text { impact-pooling and } \\
\text { minor impact on land; }\end{array}$ \\
\hline
\end{tabular}


Table A4. Cont.

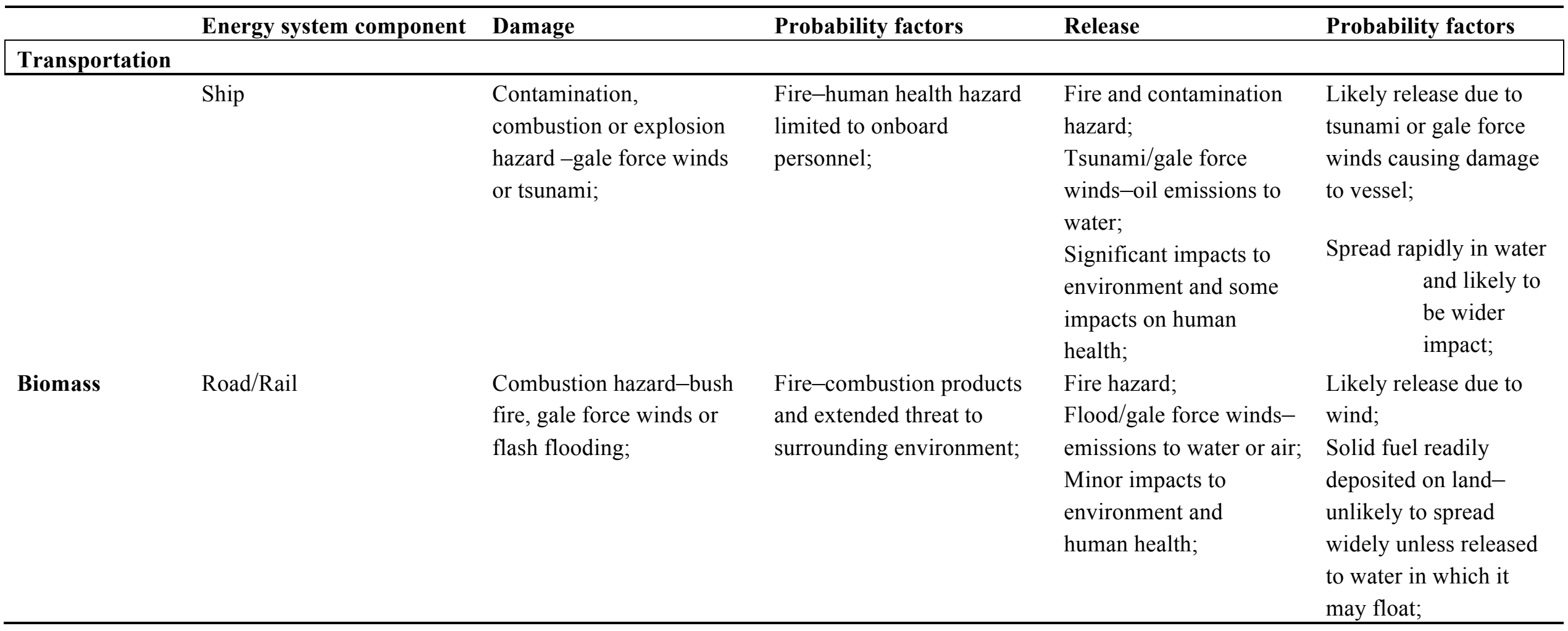

(C) 2012 by the authors; licensee MDPI, Basel, Switzerland. This article is an open access article distributed under the terms and conditions of the Creative Commons Attribution license (http://creativecommons.org/licenses/by/3.0/). 